\title{
Airborne Transmission of a Serotype 4 Fowl Adenovirus in Chickens
}

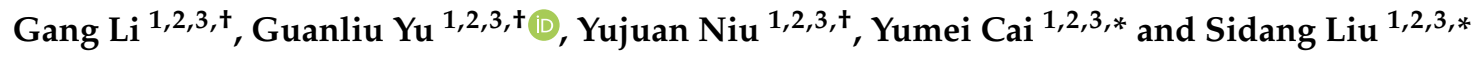 \\ 1 College of Animal Science and Technology, Shandong Agricultural University, 61 Daizong Road, \\ Tai'an 271018, Shandong, China; 18854838235@163.com (G.L.); yuguanliu@163.com (G.Y.); \\ yujuanniu@163.com (Y.N.) \\ 2 Shandong Provincial Key Laboratory of Animal Biotechnology and Disease Control and Prevention, \\ Shandong Agricultural University, 61 Daizong Road, Tai'an 271018, Shandong, China \\ 3 Shandong Provincial Engineering Technology Research Center of Animal Disease Control and Prevention, \\ Shandong Agricultural University, 61 Daizong Road, Tai'an 271018, Shandong, China \\ * Correspondence: caiyum@163.com (Y.C.); liusidang@126.com (S.L.) \\ + These authors equally contributed to this work.
}

Received: 18 January 2019; Accepted: 12 March 2019; Published: 14 March 2019

check for updates

\begin{abstract}
Serotype 4 fowl adenovirus (FAdV-4) is the main pathogen for hydropericardium syndrome (HPS) in chickens. It has caused major economic losses in the global poultry industry. Currently, FAdV-4's transmission routes in chickens remain unclear. Here we investigate the airborne transmission routes of FAdV-4 in chickens. A total of 45 ten-day-old chickens were equally divided into three groups (infected group/isolator A, airborne group/isolator B, and control group/isolator C). Of note, isolators A and B were connected by a leak-free pipe. The results showed that the virus could form a viral aerosol, detected in isolators two days post infection (dpi). The viral aerosol reached a peak at $4 \mathrm{dpi}$ in the infected group. Healthy chickens in the airborne group were infected by the virus at $8 \mathrm{dpi}$. The chickens of the airborne group demonstrated subclinical symptoms capable of shedding the virus for some time. This finding suggests that FAdV-4 can be efficiently transmitted among chickens by aerosol transmission. These findings have significant implications for developing strategies to control this infectious disease epidemic.
\end{abstract}

Keywords: chickens; fowl adenovirus serotype 4; aerosol; hydropericardium syndrome

\section{Introduction}

Serotype 4 fowl adenovirus (FAdV-4), one of 12 FAdV-4 subtypes (FAdV-1 to 12), is a member of the Aviadenovirus genus, Adenoviridae family, and contains non-enveloped and double-stranded DNA with a genome of approximately $43-46 \mathrm{~kb}$, the viral genome encodes 10 primary structural proteins (hexon, penton base, fiber, terminal protein, protein $\mu$, protein IIIa, protein $\mathrm{V}$, protein VI, protein VII, and protein VIII) and 11 non-structural proteins [E1A, E1B, E2A (DBP), E3 (ADP), E4, EP, 33 K, 52/55 K, pol, pIVaII, and $100 \mathrm{~K}]$ [1-3].

Acute avian infectious diseases with hydropericardium syndrome (HPS), inclusion body hepatitis (IBH), and gizzard erosion (GE) are always associated with FAdV infection [4], but most HPS is caused by the FAdV-4 [5]. It has resulted in severe economic losses in the global poultry industry in the last 30 years [6]. In China, there have been a large number of HPS outbreaks caused by the virus in broiler chickens since 2015 [7]. The disease has spread to most of the eastern coastal provinces. It can develop in several breeds of chickens (e.g., broilers, miscellaneous meat-type chickens, Ma chickens, layer chicks and Three-yellow chickens) [8]. Additionally, the virus also infects other birds (e.g., quails, pigeons and wild black kite) [9,10]. Among them, broilers are the main FAdV-4 hosts [11]. HPS can 
occur in broilers at 3-5 weeks of age with high mortality (up to 80\%) [12,13]. Currently, the FAdV-4 epidemic is relatively clear $[14,15]$, but the transmission route varies. Chickens could be infected by poultry vaccines previously contaminated by FAdV-4) [16], by vertical transmission and direct contact [17], or by lateral transmission (the oral-fecal route) [18]. However, to date, the airborne transmission route remains unclear.

According to previous reports, many human viruses that are devastating to animals could form a viral aerosol. These include the Newcastle disease virus (NDV), H9N2 avian influenza virus (H9N2 AIV) [19,20], infectious bronchitis virus (IBV), duck tembusu virus (DTMUV) [21,22], bovine herpes virus 1 (BHV-1) [23], porcine reproductive and respiratory syndrome virus [24,25], and foot-and-mouth disease [26]. Additionally, a subset of HPS viruses could be transmitted by airborne routes such as the quail bronchitis virus [27]. Aerosol plays a great role in spreading these viruses. However, FAdV-4's potential aerosol transmission in chickens has not been investigated to date. Therefore, to clarify the virus's route of transmission and effectively control this infectious disease epidemic, in the present study we investigated the airborne transmission of FAdV-4 in chickens.

\section{Materials and Methods}

\subsection{Ethics Statement}

In this study, all the animal experiments with chickens were aperved by the Ethic and Animal Shandong Agricultural University Animal Care and Use Committee (permit number: SDAUA-2015-003)(a). The experiments were performed in accordance with the committee's established regulations and guidelines.

\subsection{Experimental Design}

In the present study, three isolators (isolators A, B, and C) (size: $2.1 \mathrm{~m} \times 0.8 \mathrm{~m} \times 1.5 \mathrm{~m}$; Fengshi Group, Dalian, China) were used as basic equipment. The isolators were cleaned and disinfected thoroughly before beginning the experiments to ensure there were no pathogenic microorganisms. The identical positive-negative pressure isolators A and B were placed in two adjoining rooms. Of note, they were connected by a leak-free pipe ( $2 \mathrm{~m}$ long, $0.08 \mathrm{~m}$ diameter) [19]. The air pressure was adjusted to direct airflow from isolator A to B. Incoming air in isolator A (positive pressure isolator) was filtered to avoid contamination by external pathogens. A filter was added between the inoculated and airborne groups. Such a filter could stop the movement of mites or lice between isolators. The air discharged from isolator B (negative pressure isolator) was also effectively filtered to avoid spreading of pathogens and, therefore, guarantee biological safety [28] (Figure 1). Isolator C was placed in an independent house. The isolators' temperature was suitably adjusted accing to the chickens' ages. The relative humidity was $30 \% \pm 4 \%$ and the airspeed was $0.05-0.20 \mathrm{~m} / \mathrm{s}$ [29].

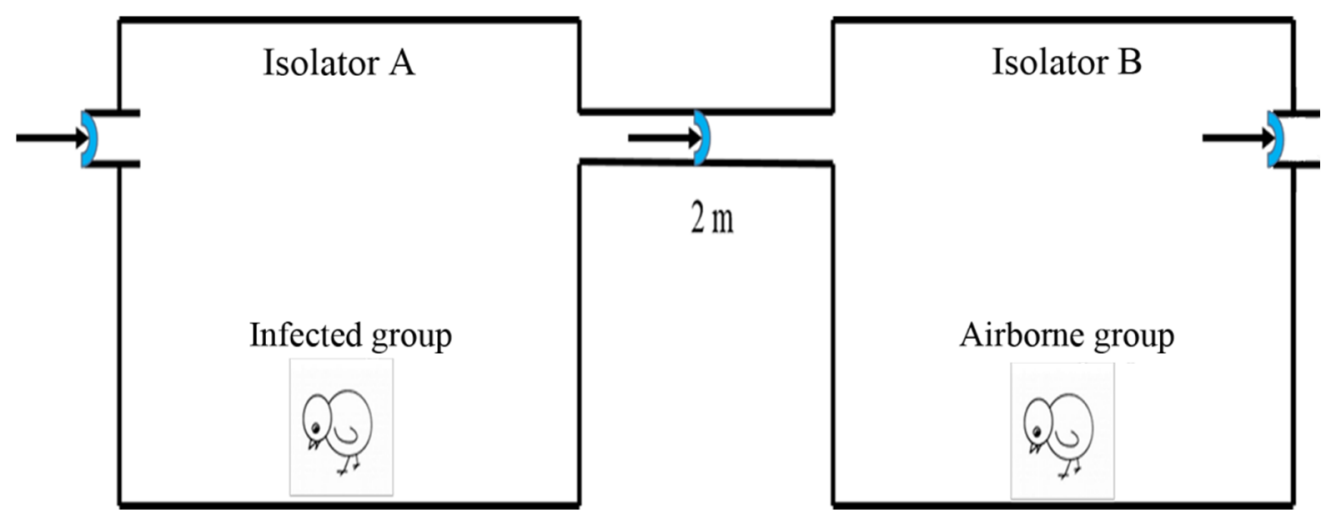

Figure 1. Schematic of FAdV-4 aerosol generation and transmission. Isolator A was a positive pressure isolator, while isolator B was a negative pressure one. The air flowed from isolator A to B. 
A total of 45 ten-day-old specific pathogen-free chickens (Sais Poultry, Jinan, China) were equally divided into three groups (i.e., infected group/isolator A, airborne group/isolator B, and control group/isolator $\mathrm{C}$ ). The chickens were reared on a net; food and water were autoclaved and refilled automatically. Feces were excreted underneath the net. During the trials' course, all the chickens' health status was observed and recorded daily. Dead chickens were necropsied, in a timely manner, in order to perform the pathological examination. All chickens were raised for 16 days and then sacrificed.

\subsection{FAdV-4 Preparation and Inoculation}

The FAdV-4 virus was diluted using Dulbecco's Modified Eagle Medium (DMEM) (Gibco, Shanghai Ke Biotechnology, Shanghai, China). The infected group was inoculated subcutaneously (s.c.) with $0.18 \mathrm{~mL}$ of viral diluent ( $10^{7} \mathrm{TCID} 50 /$ chicken) of FAdV-4 strain SDDM-4/15. In a previous study from our group, we analyzed this virus in detail [8]. The chickens in the airborne and control groups were inoculated with $0.18 \mathrm{~mL}$ DMEM/chicken.

\subsection{Clinical Observation and Post-Mortem Examination}

In the course of the study, we observed the chickens' health status. Dead chickens were necropsied to examine pathological changes during the trial. Furthermore, all chickens were euthanized after the study to detect the virus in the livers by polymerase chain reaction (PCR). FAdV-4 positive liver tissues were used to extract viral DNA. Two fragments of Hexon gene were amplified by PCR with specific primers (Table 1). The PCR was conducted in a reaction volume of $50 \mu \mathrm{L}$ containing $3 \mu \mathrm{L}$ viral genomic DNA, $\mathrm{MgCl}_{2}(8 \mathrm{mmol} / \mathrm{L}), 2 \mu \mathrm{L}$ of dNTP $(0.2 \mathrm{mmol} / \mathrm{L})$, and each primer $(100 \mathrm{mmol} / \mathrm{L})$ contained $5 \mu \mathrm{L} 10 \times$ PCR buffer and $0.25 \mu \mathrm{L}$ Ex Taq DNA polymerase (Takara, Dalian, China). The amplification programs were performed according to the following protocol: $94{ }^{\circ} \mathrm{C}$ for $5 \mathrm{~min}$, followed by 32 cycles of $94{ }^{\circ} \mathrm{C}$ for $50 \mathrm{~s}, 56^{\circ} \mathrm{C}$ for $60 \mathrm{~s}, 72^{\circ} \mathrm{C}$ for $100 \mathrm{~s}$, and a final elongation step of $8 \mathrm{~min}$ at $72{ }^{\circ} \mathrm{C}$. PCR products were analyzed by a $0.9 \%(w / v)$ agarose gel electrophoresis. Positive PCR products were subsequently purified and cloned into pEASY-T1 vector (TaKaRa, Dalian, China) according to the manufacturer's instructions. Positive clones were then sequenced using the Sanger dideoxy sequencing method (Sangon Biotech, Shanghai, China).

Table 1. Primers used in the study.

\begin{tabular}{|c|c|c|c|}
\hline Primer Name & Sequence $\left(5^{\prime}-3^{\prime}\right)$ & Product Size (bp) & GenBank No. \\
\hline FAdV (qPCR) & $\begin{array}{l}\text { F: 5'-GACGGCGGCGCAGGTGACGAAGATT-3' } \\
\text { R: 5'-TGAGACTTGGCGAAGCGACCGAGCA-3' }\end{array}$ & 126 & \\
\hline FAdV (PCR) & $\begin{array}{l}\text { F: 5'-AATTTCGACCCCATGACGCGCCAGG-3' } \\
\text { R: 5'-TGGCGA AAGGCGTACGGAAGTAAGC-3' }\end{array}$ & 508 & U46933 \\
\hline FAdV (Hexon) & $\begin{array}{c}\text { F1: 5'-TGGACATGGGGGCGACCTA-3' } \\
\text { R1: 5'-AAGGGATTGACGTTGTCCA-3' } \\
\text { F1: 5'-AACGTCAATCCCTTCAACCACC-3' } \\
\text { R1: 5'-TTGCCTGTGGCGAAAGGCG-3' }\end{array}$ & 1219 & \\
\hline
\end{tabular}

\subsection{Collection of Air Sample}

Before the beginning of the trial, the air samples in isolators $\mathrm{A}, \mathrm{B}$, and $\mathrm{C}$ were collected and evaluated to guarantee the isolators were free of pathogenic contamination. Subsequently, air samples in all isolators were collected by AGI-30 (All Glass Impinger, Liaoyang, China). Collection was performed at a flow rate of $12.5 \mathrm{~L} / \mathrm{mL}$ for $40 \mathrm{~min}$ at 2, 4, 8, 12, and $16 \mathrm{dpi}$ [28]. We used $50 \mathrm{~mL}$ sterilized phosphate buffer solution (PBS. pH 7.2, containing $1000 \mathrm{U} / \mathrm{mL}$ penicillin, $1 \mathrm{mg} / \mathrm{mL}$ streptomycin) as a sampling medium. All samples were stored at $4{ }^{\circ} \mathrm{C}$ and used within $24 \mathrm{~h}$. Air collection fluid was first spun at $8000 \times g$ for $30 \mathrm{~min}$ to remove the pelleted bacteria and dust. It was then centrifuged at $100,000 \times g$ for $2 \mathrm{~h}$ to collect the viral pellet. The viral pellet was diluted with $0.6 \mathrm{~mL}$ PBS. Viral DNA was extracted by a DNeasy Tissue kit (Qiagen, Hilden, Germany) to detect the concentration of FAdV-4 aerosol in the isolators. Quantification was performed by qualitative real-time PCR (qPCR) with 
specific primers (Table 1). qPCR was performed using the UltraSYBR Mixture (High ROX) (CWBIO, Beijing, China) and the ABI PRISM 7500 Real-time PCR System (Applied Biosystems, Foster City, CA, USA). The qPCR was conducted in a total volume of $20 \mu \mathrm{L}$, following the manufacturer's instructions. The amplification steps were set as follows: stage $1,95^{\circ} \mathrm{C}$ for $10 \mathrm{~min}$, stage 2,40 cycles of denaturation at $95{ }^{\circ} \mathrm{C}$ for $15 \mathrm{~s}$ and at $60^{\circ} \mathrm{C}$ for $60 \mathrm{~s}$, followed by a dissociation curve analysis. Each sample was analyzed in triplicate.

\subsection{Collection of Serum, Liver, Oral, and Cloaca Samples}

In this study, in order to confirm the presence of infectious FAdV-4, we detected the viremia and the FAdV-4 positive rate of the liver. Five blood samples were obtained randomly from the jugular vein of the chickens in each group at $0,2,4,8,12$, and $16 \mathrm{dpi}$. The serums were separated from the blood samples by centrifugation. A portion of the product was used to detect FAdV-4 load by qPCR. The remainder was used to examine antibody responses against FAdV-4 by enzyme-linked immunosorbent assay kit (Biochek USA Corporation, Scarborough, ME, USA).

Ten oral and cloacal swabs were randomly collected from each group at $0,2,4,8,12$, and $16 \mathrm{dpi}$. The swabs were used to identify the virus' shedding by PCR.

\subsection{Hexon Gene Sequence Alignment}

In the present study, the Clustal W method in the MegAlign program of DNAStar was used to further confirm airborne transmission of the virus. This method allowed the alignment of amplified fragments (2524 bp, linked by the two fragments) of FAdV-4's Hexon gene in the virus-positive liver of chickens between the infected group and the airborne group.

\section{Results}

\subsection{Clinical Observations and Necropsy/Post-Mortem Findings}

In the infected group, the chickens showed signs of depression after 1 dpi. Additionally, three died at $2 \mathrm{dpi}$, three at $4 \mathrm{dpi}$, four at $5 \mathrm{dpi}$, two at $6 \mathrm{dpi}$, and one at $7 \mathrm{dpi}$. The infected group's overall mortality was $86.7 \%$. Necropsies of the dead chickens revealed visible pericardial effusion and liver necrosis (figure not shown). No obvious pathological changes were observed in the chickens of the airborne and control groups (figure not shown). We did not record any death in the airborne and control groups until the experiment ended (Figure 2).

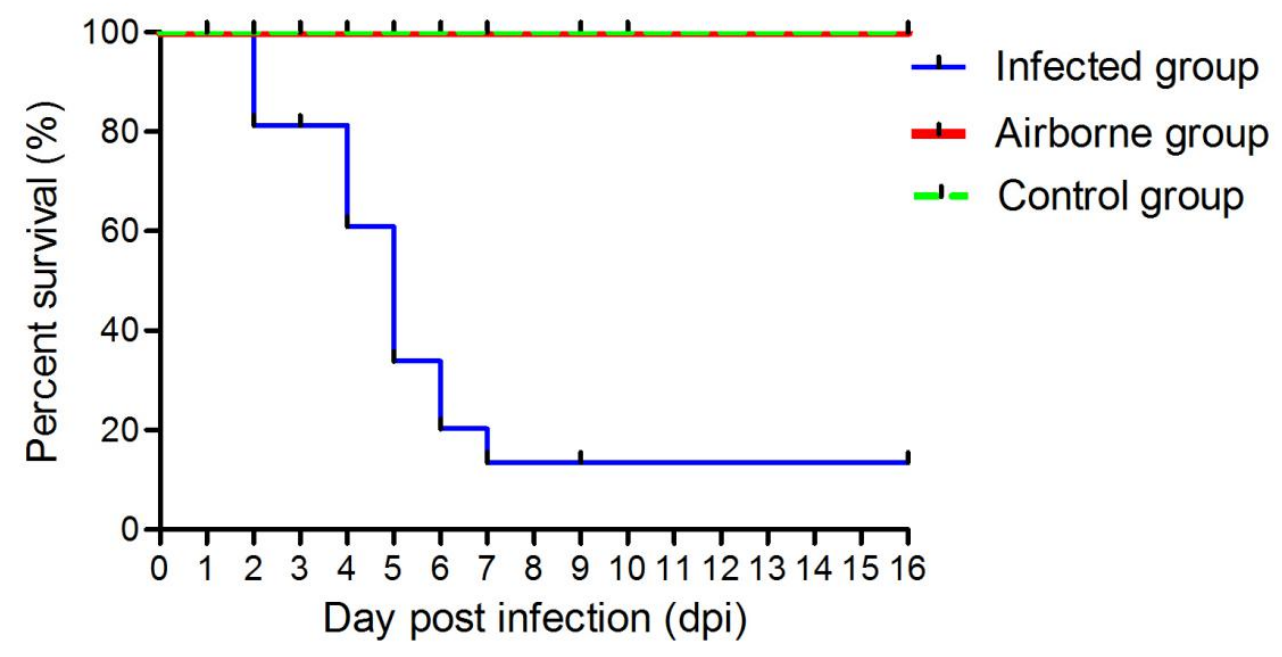

Figure 2. Survival curve analysis of experimental chickens at different time points post infection. Note: the green line (airborne group) is not obvious because it overlaps with the black line (control group). 


\subsection{Detection of FAdV-4 Aerosol}

In this study, the FAdV-4's aerosol was detected in isolator A at $2 \mathrm{dpi}$, at a concentration of $9.16 \times 10^{3}$ copies $/ \mathrm{m}^{3}$. The maximum concentration of the viral aerosol recorded was $4.75 \times 10^{5}$ copies $/ \mathrm{m}^{3}$ at $4 \mathrm{dpi}$. It remained there until the end of the trial. In isolator $\mathrm{B}$, the concentration of viral aerosol was $9.68 \times 10^{2}$ copies $/ \mathrm{m}^{3}$ at 2 dpi. Its maximum concentration was $1.64 \times 10^{5}$ copies $/ \mathrm{m}^{3}$ at $8 \mathrm{dpi}$. Moreover, the virus aerosol concentrations kept increasing, reaching the same level as isolator A at $16 \mathrm{dpi}$ (Figure 3). No viral aerosol was detected in control group.

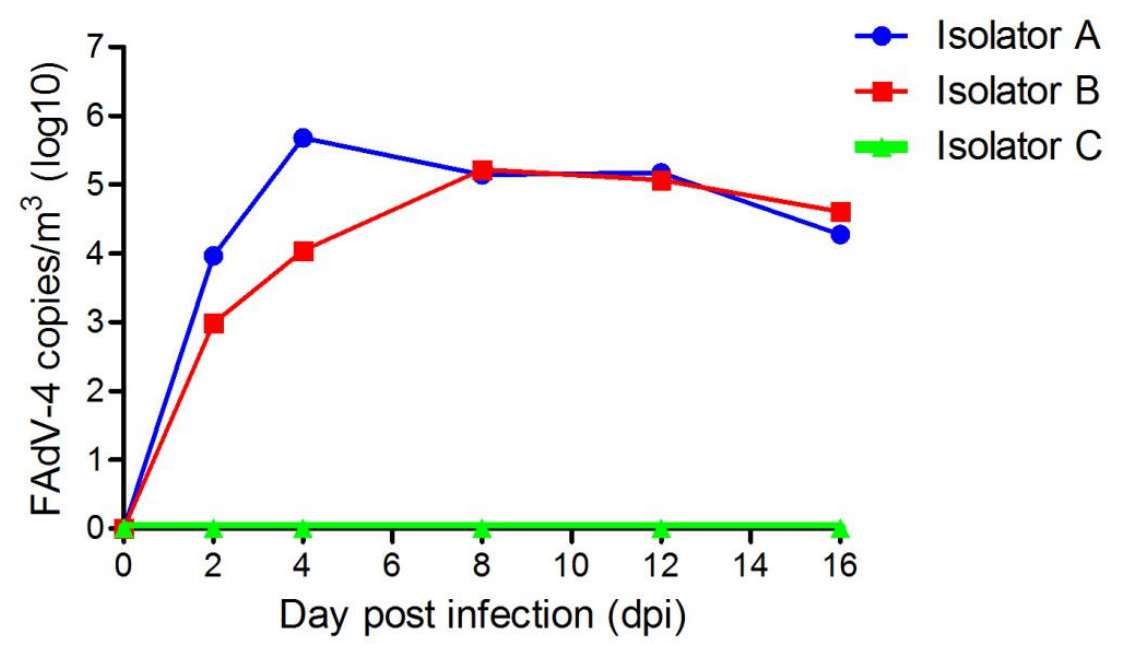

Figure 3. The concentration of the FAdV-4 aerosols in isolator A and B at different time points post infection.

\subsection{Viremia and FAdV-4 Antibody}

Five chickens per group were tested for viremia and antibody at each time point. In the infected group, viremia occurred at $2 \mathrm{dpi}$ and lasted until $16 \mathrm{dpi}$. In the airborne group, viremia was detected in one chicken at $8 \mathrm{dpi}$ and another one at $12 \mathrm{dpi}$. Additionally, two chickens showed viremia at $16 \mathrm{dpi}$ (Figure 4). Seroconversion was detected in the chickens at 4 dpi (Figure 5). Chickens in the infected group showed the highest antibody level at $12 \mathrm{dpi}$. In the airborne group, only one chicken showed seroconversion at $16 \mathrm{dpi}$. Neither viremia nor antibody titers were observed in the control group.

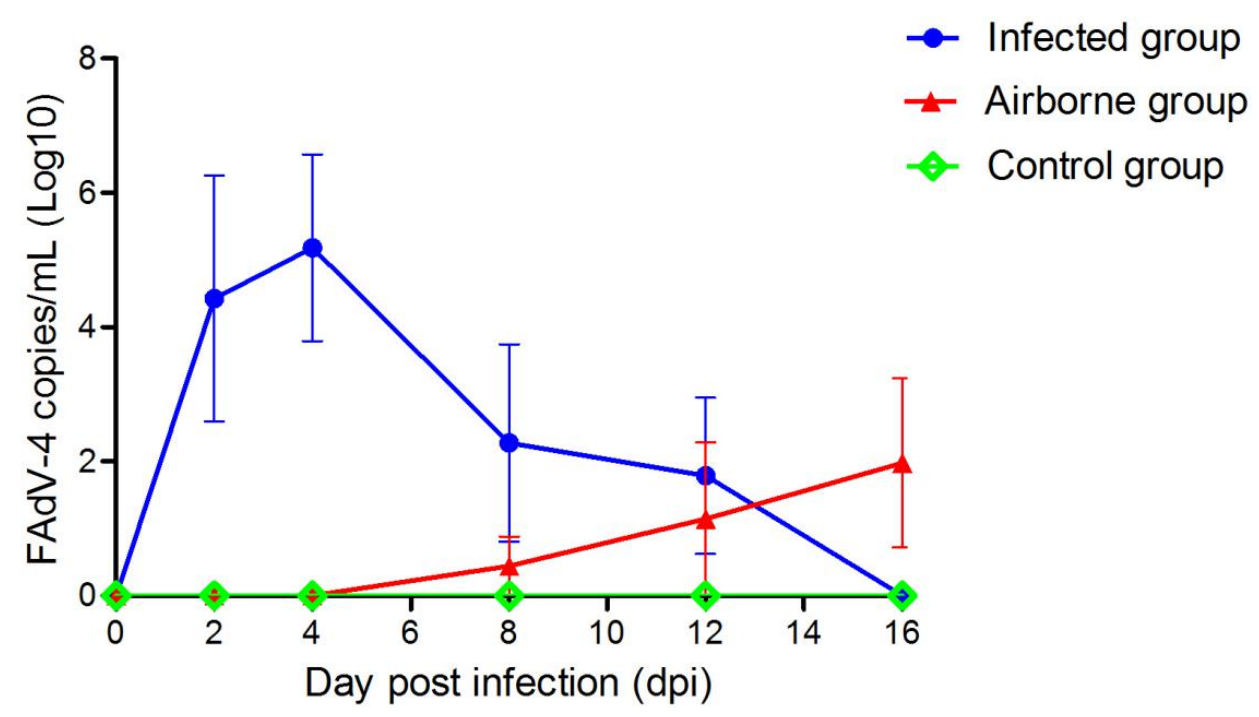

Figure 4. Viral genome in the serum of chickens at different time points. The data were presented as the mean \pm standard deviation. 


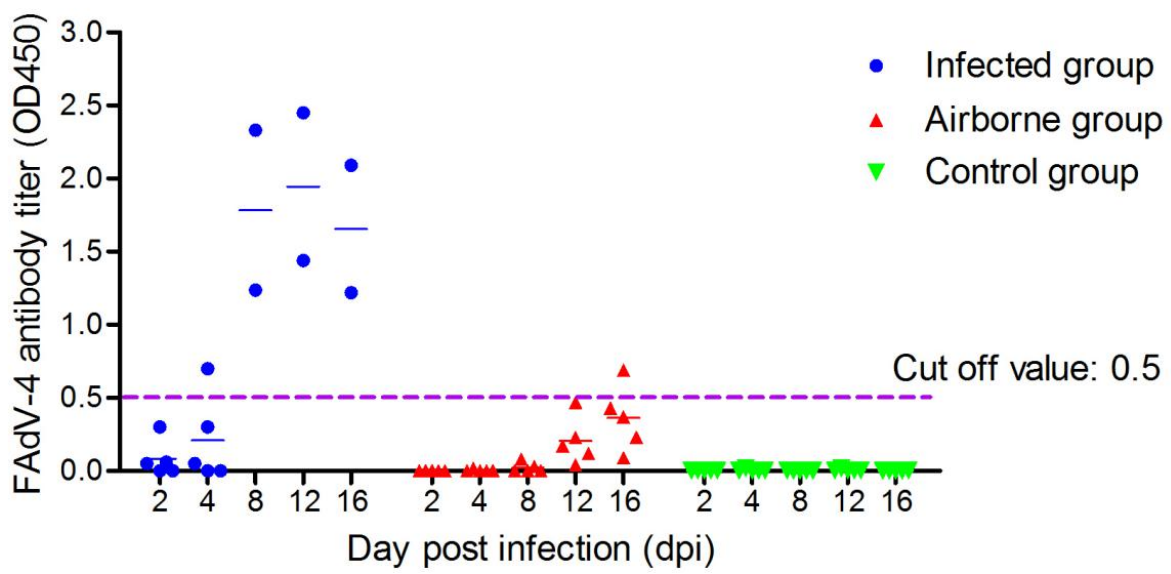

Figure 5. Antibody titers. Values were higher than 0.5 , indicating that the serum antibody was positive.

\subsection{Virus Shedding}

To detect virus shedding in the surviving chickens in all groups, oral and cloacal swabs were collected from 2 to $16 \mathrm{dpi}$ and examined by PCR. In the infected group, shedding of viruses appeared in $40 \%(4 / 10)$ and $60 \%(6 / 10)$ of oral and cloacal swabs at 2 dpi. Additionally, all chickens $(2 / 2)$ shed viruses from 8 to $16 \mathrm{dpi}$. However, in the airborne group, $10 \%(1 / 10)$ of the cloacae swabs was viral DNA-positive at $4 \mathrm{dpi}$, and at $16 \mathrm{dpi}, 60 \%(6 / 10)$ chickens were positive. No viral DNA-positive was detected in the control group (Figures 6 and 7 ).

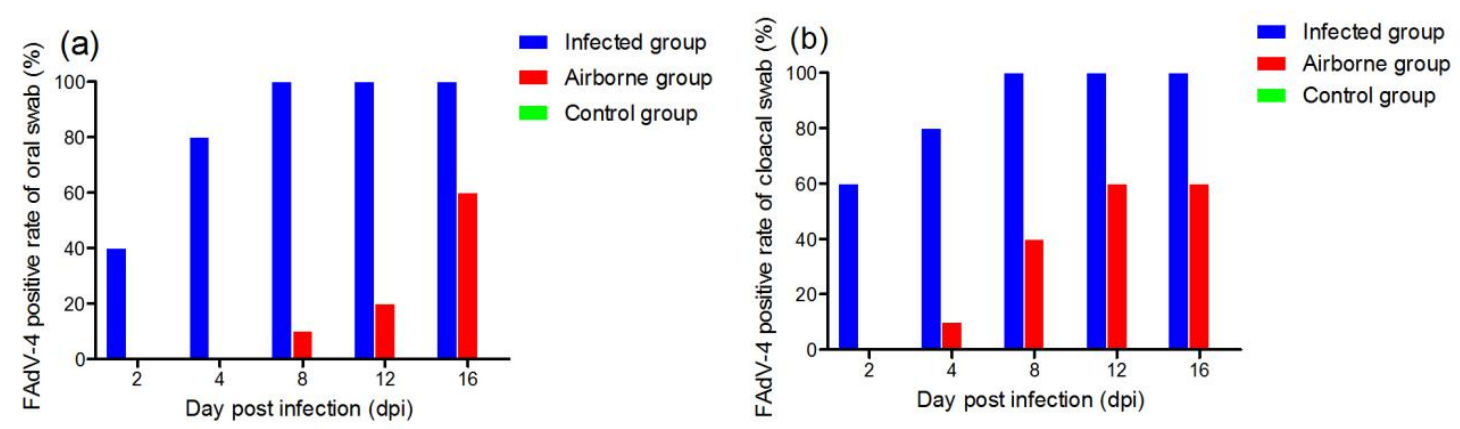

Figure 6. FAdV-4 positive rates of oral swab (a) and cloacal swab (b) at different days post infection.

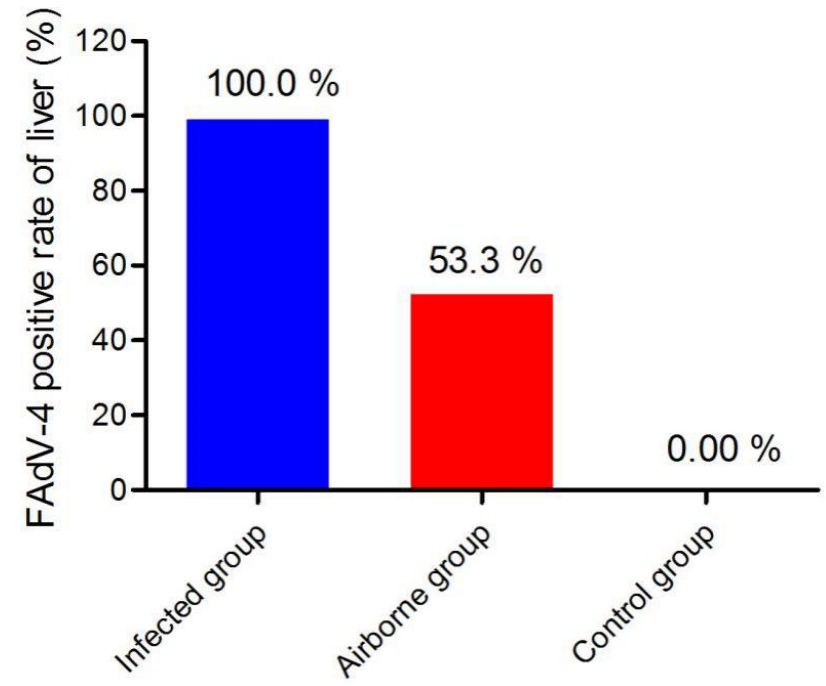

Figure 7. FAdV-4 positive rates of liver samples in different groups. Notes: liver samples of each group were collected from dead or healthy chickens from 2 dpi to $16 \mathrm{dpi}$. 


\subsection{Viral DNA Detection in the Liver}

As shown in Figure 7, FAdV-4 positive rate in the liver reached up to $100 \%(15 / 15)$ in the infected group. In the airborne group, $53.3 \%(8 / 15)$ of the liver samples were infected by FAdV-4. No viral DNA was detected in the control group.

In the infected group, viral DNA was detected in all $(15 / 15,100 \%)$ tissue samples collected from dead or live chickens. In the airborne group, 53.3\% (8/15) of the liver samples collected from the sacrificed chickens were positive for viral DNA. No viral DNA-positive was detected in the control group.

\subsection{Sequence Alignment of Hexon Gene}

In this study, the Hexon gene sequence analysis revealed 99.9\% sequence identity (at the nucleotide level) between the infected group isolate and the airborne group strain. This result provided sufficient evidence to further confirm that the virus in the airborne group originated from the infected group.

\section{Discussion}

FAdV-4, a non-enveloped, double-stranded DNA virus, plays a major role in the pathogenesis of HPS in broilers aged 3-5 weeks [30]. The disease was first reported in Angara Goth (also named Angara disease), Pakistan, in 1987. There were subsequent outbreaks in India, South Asia, China, Japan, South Korea, Eastern Europe, Mexico, and North America. It has caused huge economic losses to the poultry industry worldwide [31]. To effectively control the spread and epidemic of this infectious disease, an exhaustive study of FAdV-4's transmission route is required.

To the best of our knowledge, this is the first study to evaluate airborne transmission of FAdV-4. During the trials, dynamic monitoring of FAdV-4 aerosol generation and transmission revealed FAdV-4 in air samples from isolators A, B, and C. FAdV-4 aerosol concentration of isolators A and B peaked at $4.75 \times 10^{5}$ copies $/ \mathrm{m}^{3}$ air at $4 \mathrm{dpi}$, and $1.64 \times 10^{5}$ copies $/ \mathrm{m}^{3}$ air at $8 \mathrm{dpi}$, respectively. Both remained at higher concentrations for a long time. Such findings indicate that FAdV-4's aerosol model generation and transmission was successfully established.

We observed a positive correlation between the concentrations of virus aerosols and the number of infected chickens [32]. However, in the present study, as the number of infected live chickens decreased (Figure 1), the concentration of the viral aerosol of the infected group did not reduce (Figure 2). This could be caused by the virus released from feces into the air. Furthermore, the aerosol concentration was also linked to the body weight of the chickens and the accumulation of aerosol. Additional influencing factors were temperature [33], speed of air current [34], the chickens' activity, and herd density [35].

In the present study, the viral aerosol in the A and B isolators could be detected at $2 \mathrm{dpi}$, which indicated that the virus could proliferate rapidly in the air of isolators. The virus excreted by oral and cloaca of infected chickens, other transmission routes (e.g., contact transmission) also accelerate the spread of FAdV-4 in chickens. However, detection of the viraemia and FAdV-4 positive antibody of chickens in the airborne group occurred at 8 and 16 dpi respectively. Of note, these time points were significantly later than those in the infected group (i.e., 2 and 8 dpi respectively) (Figures 3 and 4). These different time points may be due to the lower concentration of FAdV-4 aerosol in the airborne group of 8 days ago (Figure 2). The lower the viral aerosols' concentration, the less likely the chickens were to be infected, consistent with the above phenomenon.

Here, based on FAdV-4's aerosol concentration indices, FAdV-4 antibody titer, viremia, sequence alignment, FAdV-4 positive rates of oral swab, cloacal swab, and liver in the airborne group, we can conclude that the chickens in the airborne group have been infected by FAdV-4 aerosol originating from the infected group. However, the chickens didn't show significant pathological lesions (e.g., higher antibody titer or mortality rate). This may be due to the development of a subclinical infection, which usually does not show any clinical feature, and can only be found by immunological detection [36]. Of 
note, infections pose greater potential risks for the poultry industry because virus infected fowls are still alive and could continue to excrete the virus into the surroundings through the feces or oral cavity.

\section{Conclusions}

In conclusion, our findings provide adequate evidence that FAdV-4 could spread by aerosols in chickens. Thus, regular ventilation and disinfection in the breeding environment are critical measures to block FAdV-4's spread.

Author Contributions: G.L., G.Y., and Y.N. completed most of the experiments; Y.C. and S.L. provide the experimental materials and reviewed the manuscript. All authors have read and approved the manuscript for publication. Thanks for all the authors' contribution to the study.

Acknowledgments: This study was supported by the National Natural Science Foundation of China (31672518) and the Funds of Shandong "Double Tops" Program.

Conflicts of Interest: The authors declare no conflict of interest.

\section{References}

1. Griffin, B.D.; Nagy, E. Coding potential and transcript analysis of fowl adenovirus 4: Insight into upstream ORFs as common sequence features in adenoviral transcripts. J. Gen. Virol. 2011, 92, 1260-1272. [CrossRef] [PubMed]

2. Xie, Z.; Luo, S.; Fan, Q.; Xie, L.; Liu, J.; Xie, Z. Detection of antibodies specific to the nonstructural proteins of fowl adenoviruses in infected chickens but not in vaccinated chickens. Avian Pathol. 2013, 42, 491-496. [CrossRef] [PubMed]

3. Li, P.H.; Zheng, P.P.; Zhang, T.F.; Wen, G.Y.; Shao, H.B.; Luo, Q.P. Fowl adenovirus serotype 4: Epidemiology, pathogenesis, diagnostic detection, and vaccine strategies. Poult. Sci. 2017, 96, 2630-2640. [CrossRef] [PubMed]

4. Pan, Q.; Liu, L.L.; Wang, Y.Q.; Zhang, Y.P.; Qi, X.L.; Liu, C.J.; Gao, Y.L.; Wang, X.M.; Cui, H.Y. The first whole genome sequence and pathogenicity characterization of a fowl adenovirus 4 isolated from ducks associated with inclusion body hepatitis and hydropericardium syndrome. Avian Pathol. 2017, 46, 571-578. [CrossRef] [PubMed]

5. Schachner, A.; Marek, A.; Jaskulska, B.; Bilic, I.; Hess, M. Recombinant FAdV-4 fiber-2 protein protects chickens against hepatitis-hydropericardium syndrome (HHS). Vaccine 2014, 32, 1086-1092. [CrossRef] [PubMed]

6. Dahiya, S.; Srivastava, R.N.; Hess, M.; Gulati, B.R. Fowl adenovirus serotype 4 associated with outbreaks of infectious hydropericardium in Haryana, India. Avian Dis. 2002, 46, 230-233. [CrossRef]

7. Zhang, T.; Jin, Q.Y.; Ding, P.Y.; Wang, Y.B.; Chai, Y.X.; Li, Y.F.; Liu, X.; Luo, J.; Zhang, G.P. Molecular epidemiology of hydropericardium syndrome outbreakassociated serotype 4 fowl adenovirus isolates in central China. Virol. J. 2016, 13, 188. [CrossRef] [PubMed]

8. Niu, Y.J.; Sun, W.; Zhang, G.H.; Qu, Y.J.; Wang, P.F.; Sun, H.L.; Xiao, Y.H.; Liu, S.D. Hydropericardium syndrome outbreak caused by fowl adenovirus serotype 4 in China in 2015. J. Gen. Virol. 2016, 97, 2684.

9. Naeem, K.; Akram, H. Hydropericardium syndrome outbreak in a pigeon flock. Vet. Rec. 1995, 136, $296-297$. [CrossRef]

10. Kumar, R.; Kumar, V.; Asthana, M.; Shukla, S.K.; Chandra, R. Isolation and Identification of a Fowl Adenovirus from Wild Black Kites (Milvus migrans). J. Wildl. Dis. 2010, 46, 272. [CrossRef]

11. Grgić, H.; Poljak, Z.; Sharif, S.; Nagy, É. Pathogenicity and cytokine gene expression pattern of a serotype 4 fowl adenovirus isolate. PLoS ONE 2013, 8, e77601. [CrossRef]

12. Li, H.; Wang, J.; Qiu, L.; Han, Z.; Liu, S. Fowl adenovirus species $C$ serotype 4 is attributed to the emergence of hepatitis-hydropericardium syndrome in chickens in China. Infect. Genet. Evol. 2016, 45, 230-241. [CrossRef] 
13. Liu, Y.; Wan, W.; Gao, D.; Li, Y.; Yang, X.; Liu, H.; Yao, H.; Chen, L.; Wang, C.; Zhao, J. Genetic characterization of novel fowl aviadenovirus 4 isolates from outbreaks of hepatitis-hydropericardium syndrome in broiler chickens in China. Emerg. Microbes Infect. 2016, 5, e117. [CrossRef]

14. Niu, Y.; Sun, Q.; Zhang, G.; Sun, W.; Liu, X.; Xiao, Y.; Shang, Y.; Liu, S. Epidemiological investigation of outbreaks of fowl adenovirus infections in commercial chickens in China. Transbound. Emerg. Dis. 2017, 65, e121-e126. [CrossRef]

15. Guan, R.; Tian, Y.; Han, X.; Yang, X.; Wang, H. Complete genome sequence and pathogenicity of fowl adenovirus serotype 4 involved in hydropericardium syndrome in Southwest China. Microb. Pathog. 2018, 117, 290-298. [CrossRef]

16. Li, Y.; Fu, J.; Chang, S.; Fang, L.; Cui, S.; Wang, Y.; Cui, Z.; Zhao, P. Isolation, identification, and hexon gene characterization of fowl adenoviruses from a contaminated live Newcastle disease virus vaccine. Poult. Sci. 2016, 96, 1094. [CrossRef]

17. Grgíc, H.; Philippe, C.; Ojkíc, D.; Nagy, É. Study of vertical transmission of fowl adenoviruses. Can. J. Vet. Res. 2006, 70, 230.

18. Balamurugan, V.; Kataria, J.M. The Hydropericardium Syndrome in Poultry-A Current Scenario. Vet. Res. Commun. 2004, 28, 127-148. [CrossRef]

19. Li, X.; Chai, T.; Wang, Z.; Song, C.; Cao, H.; Liu, J.; Zhang, X.; Wang, W.; Yao, M.; Miao, Z. Occurrence and transmission of Newcastle disease virus aerosol originating from infected chickens under experimental conditions. Vet. Microbiol. 2009, 136, 226-232. [CrossRef]

20. Lv, J.; Wei, B.; Yang, Y.; Yao, M.; Cai, Y.; Gao, Y.; Xia, X.; Zhao, X.; Liu, Z.; Li, X. Experimental transmission in guinea pigs of H9N2 avian influenza viruses from indoor air of chicken houses. Virus Res. 2012, 170, 102-108. [CrossRef]

21. Cumming, R.B. Studies on Australian infectious bronchitis virus. IV. Apparent farm-to-farm airborne transmission of infectious bronchitis virus. Avian Dis. 1970, 14, 191-195. [CrossRef]

22. Xuesong, L.; Ying, S.; Qinfang, L.; Ying, W.; Guoxin, L.; Qiaoyang, T.; Yuee, Z.; Sidang, L.; Zejun, L. Airborne Transmission of a Novel Tembusu Virus in Ducks. J. Clin. Microbiol. 2015, 53, 2734-2736.

23. Mars, M.H.; de Jong, M.C.M.; Van Maanen, C.; Hage, J.J.; Van Oirschot, J.T. Airborne transmission of bovine herpesvirus 1 infections in calves under field conditions. Vet. Microbiol. 2000, 76, 1-13. [CrossRef]

24. Brockmeier, S.L.; Lager, K.M. Experimental airborne transmission of porcine reproductive and respiratory syndrome virus and Bordetella bronchiseptica. Vet. Microbiol. 2002, 89, 267-275. [CrossRef]

25. Kristensen, C.S.; Bøtner, A.; Takai, H.; Nielsen, J.P.; Jorsal, S.E. Experimental airborne transmission of PRRS virus. Vet. Microbiol. 2004, 99, 197-202. [CrossRef]

26. Amaral-Doel, C.M.; Gloster, J.; Valarcher, J.F. Airborne transmission of foot-and-mouth disease in pigs: Evaluation and optimisation of instrumentation and techniques. Vet. J. 2009, 179, 219-224. [CrossRef]

27. Dubose, R.T. Quail Bronchitis1. J. Wildl. Dis. 1967, 3, 10-13.

28. Hao, H.; Chao, L.; Qiu, Y.; Wang, F.; Ai, W.; Jing, G.; Wei, L.; Li, X.; Sun, L.; Jie, W. Generation, transmission and infectiosity of chicken MDV aerosols under experimental conditions. Vet. Microbiol. 2014, 172, 400-406. [CrossRef]

29. Lowen, A.C.; Steel, J.; Mubareka, S.; Palese, P. High temperature $\left(30{ }^{\circ} \mathrm{C}\right)$ blocks aerosol but not contact transmission of influenza virus. J. Virol. 2008, 82, 5650-5652. [CrossRef]

30. Yu, G.; Wang, Y.; Zhang, M.; Lin, Y.; Tang, Y.; Diao, Y. Pathogenic, Phylogenetic, and Serological Analysis of Group I Fowl Adenovirus Serotype 4 SDSX Isolated From Shandong, China. Front. Microbiol. 2018, 9, 2772. [CrossRef]

31. Niczyporuk, J.S. Phylogenetic and geographic analysis of fowl adenovirus field strains isolatedfrom poultry in Poland. Arch. Virol. 2016, 161, 33-42. [CrossRef]

32. Hugh-Jones, M.; Allan, W.H.; Dark, F.A.; Harper, G.J. The evidence for the airborne spread of Newcastle disease. J. Hyg. 1973, 71, 325-339. [CrossRef]

33. Alexander, D.J. The epidemiology and control of avian influenza and Newcastle disease. J. Comp. Pathol. 1995, 112, 105. [CrossRef]

34. Jones, A.M.; Harrison, R.M. The effects of meteorological factors on atmospheric bioaerosol concentrations-A review. Sci. Total Environ. 2004, 326, 151-180. [CrossRef] 
35. Tseng, C.C.; Li, C.S. Collection efficiencies of aerosol samplers for virus-containing aerosols. J. Aerosol Sci. 2005, 36, 593-607. [CrossRef]

36. Chen, F.Y. Veterinary Lemology, 6th ed.; China Agriculture Press: Beijing, China, 2016; pp. 12-13.

(C) 2019 by the authors. Licensee MDPI, Basel, Switzerland. This article is an open access article distributed under the terms and conditions of the Creative Commons Attribution (CC BY) license (http://creativecommons.org/licenses/by/4.0/). 